\title{
KEMAMPUAN SISWA KELAS X SMA CINTA BUDAYA MENGANALISIS TEKS NEGOSIASI TAHUN PEMBELAJARAN 2017/2018
}

\author{
Oleh \\ Marlond Matheus (marlondmatheus@yahoo.com) \\ Atika Wasilah, S.Pd., M.Pd. (atika_wasilah@yahoo.co.id)
}

\begin{abstract}
ABSTRAK
Melalui penelitian ini kita akan mengetahui kemampuan menganalisis teks negosiasi melalui analisis struktur dan kaidah kebahasaan oleh siswa kelas X SMA Cinta Budaya Tahun Pembelajaran 2017/2018. Terdapat 193 siswa yang menjadi populasi dalam penelitian ini. Namun, sampelnya hanya berjumlah 37 orang siswa, yang dipilih dengan menggunakan teknik simple random sampling. Penelitian ini menggunakan metode penelitian deskriptif. Selain itu, penelitian ini juga menggunakan tes essay (uraian) sebagai instrumennya.

Secara keseluruhan, diperoleh hasil bahwa kemampuan menganalisis teks negosiasi siswa tergolong baik. Nilai kemampuan analisis struktur yang tertinggi berada pada angka 97,5 dan nilai terendahnya adalah 60. Sedangkan nilai kemampuan analisis kaidah kebahasaan yang tertinggi adalah 77,5 dan nilai terendahnya yaitu 52,5. Nilai rata-rata kemampuan analisis struktur adalah 77 , dan nilai rata-rata kemampuan analisis kaidah kebahasaan adalah 71. Mengenai persentase kategori kemampuan analisis struktur, diperoleh data bahwa 17 (46\%) siswa berkemampuan sangat baik, 12 (32\%) siswa berkemampuan baik, dan $8(22 \%)$ siswa berkemampuan cukup. Sementara untuk kemampuan analisis kaidah kebahasaan, $30(81 \%)$ siswa berkemampuan baik, 4 (11\%) siswa berkemampuan cukup, dan $3(8 \%)$ siswa kurang mampu menganalisis kaidah kebahasaan teks negosiasi. Dari beberapa data tersebut, dapat disimpulkan bahwa kemampuan siswa kelas X SMA Cinta Budaya Tahun Pembelajaran 2017/2018 dalam menganalisis teks negosiasi tergolong baik.
\end{abstract}

Kata kunci: teks negosiasi, sma cinta budaya, struktur kaidah bahasa

\section{PENDAHULUAN}

Kurikulum 2013 yang mengalami revisi pada tahun 2016 silam tidak hanya mempertahankan Bahasa Indonesia dalam mata pelajaran wajib di sekolah, tetapi 
juga menegaskan pentingnya keberadaan Bahasa Indonesia sebagai penghela ilmu pengetahuan. Artinya, Bahasa Indonesia bukan hanya menjadi objek pengetahuan, tetapi juga menjadi sarana komunikasi untuk memperoleh dan mengembangkan ilmu pengetahuan.

Pada Kurikulum 2013 ditegaskan bahwa pembelajaran Bahasa Indonesia saat ini merupakan pembelajaran berbasis teks, dengan harapan dapat memberi kesempatan kepada peserta didik untuk mengembangkan berbagai jenis struktur berpikir yang berbeda satu sama lain. Mahsun (2014: 95) menyebutkan, "Semakin banyak jenis teks yang dikuasai, maka semakin banyak struktur berpikir yang dikuasai peserta didik". Salah satu jenis teks yang harus dikuasai itu adalah teks negosiasi.

Teks negosiasi adalah bentuk interaksi sosial yang berfungsi untuk mencapai kesepakatan di antara pihak-pihak yang bersangkutan. Teks negosiasi juga dapat dikatakan sebagai salah satu bentuk interaksi sosial untuk mengompromikan keinginan yang berbeda ataupun bertentangan. Kosasih (2013: 219) berpendapat bahwa teks negosiasi dapat diartikan sebagai upaya untuk mencapai suatu kesepakatan melalui suatu bentuk diskusi atau percakapan.

Dalam Buku Guru Bahasa Indonesia Kelas X SMA (Kemdikbud, 2015: 16) dikatakan bahwa salah satu kompetensi yang harus dikuasai siswa adalah menganalisis teks negosiasi.

Menganalisis berarti melakukan analisis. Menurut Wiradi (2009: 20) analisis adalah serangkaian perbuatan meneliti, mengurai, membedakan, memilah sesuatu untuk digolongkan serta dikelompokkan berdasarkan keterikatan serta penafsiran makna dari setiap kriteria. Analisis juga berarti penguraian suatu pokok atas berbagai bagiannya dan penelaahan bagian itu sendiri serta hubungan antarbagian untuk memperoleh pemahaman arti keseluruhan (Depdiknas, 2008). Menyesuaikan dengan kemampuan siswa kelas $\mathrm{X}$, analisis yang dilakukan murid tentunya tidak sama tingkatannya dengan analisis seorang ahli bahasa. Artinya, analisis di sini hanya sebatas penyelidikan untuk menentukan struktur dari setiap tuturan negosiasi dan jenis kalimat yang menandai kaidah kebahasaan teks tersebut. 
Dalam usaha menemukan kemampuan siswa menganalisis teks negosiasi ini juga terdapat beberapa masalah yang perlu diperhatikan. Misalnya masalah yang disebutkan Susanti Dewi dkk (dalam artikel jurnal Implementasi Pembelajaran Menulis Teks Negosiasi Berdasarkan Kurikulum 2013) bahwa perencanaan pembelajaran yang dibuat oleh guru masih memiliki beberapa kelemahan; yaitu materi pelajaran tidak diperinci, metode yang digunakan tidak disesuaikan dengan metode yang tertuang dalam Kurikulum 2013, guru tidak merinci langkah-langkah pembelajaran pada tiap pertemuan, pada bagian pendahuluan guru tidak merumuskan kegiatan-kegiatan yang dilakukan oleh peserta didik, dan pada bagian penutup guru tidak mencantumkan program pengayaan serta remidi dalam RPP.

Beberapa data penelitian terdahulu yang dapat dijadikan acuan antara lain penelitian dengan metode eksperimen yang dilakukan oleh Bangun (dalam Pengaruh Model Pembelajaran Inkuiri terhadap Kemampuan Menganalisis Teks Negosiasi oleh Siswa Kelas X SMA Negeri 2 Kabanjahe Tahun Pembelajaran 2015/2016, 2016) dengan nilai rata-rata 69,06 untuk pre-test dan 78,59 untuk post-test. Lalu, penelitian kedua dengan metode korelasional oleh Hasibuan (dalam Hubungan Pemahaman Isi, Struktur, dan Ciri Kebahasaan dengan Kemampuan Menganalisis Teks Negosiasi Siswa Kelas XI SMA Swasta Krakatau Medan Tahun Pembelajaran 2016/2017, 2016) menemukan bahwa nilai rata-rata siswa untuk kemampuan ini adalah 79,03.

Data yang berhubungan dengan lokasi penelitian mengacu kepada eksperimen oleh Harliani (dalam Peningkatan Kemampuan Menganalisis Keterkaitan Unsur Suatu Cerpen dengan Kehidupan Sehari-hari melalui Metode Jigsaw pada Siswa Kelas X SMA Cinta Budaya) yang menyatakan bahwa nilai rata-rata post-test pada penelitian ini adalah 78,84. Namun, nilai rata-rata pre-test siswa kurang memuaskan yaitu 70,06. Harliani juga menyebutkan bahwa rendahnya nilai pre-test juga menggambarkan kurangnya minat siswa sebelum penggunaan metode jigsaw.

Rendahnya minat siswa dalam menganalisis juga diketahui melalui wawancara dengan Bernard Nainggolan, S.Pd. selaku guru di SMA Cinta Budaya 
yang mengatakan bahwa siswa lebih tertarik menulis daripada melakukan kegiatan menganalisis. Hal ini membuat guru harus mencari dan mencoba beberapa metode pembelajaran yang menarik dan benar-benar cocok bagi siswa di sekolah ini.

\section{METODE PENELITIAN}

Untuk menjawab permasalahan yang ada dalam penelitian ini yaitu kemampuan siswa menganalisis teks negosiasi, penulis menggunakan metode deskriptif, dengan pendekatan kualitatif. Penelitian deskriptif merupakan penelitian yang berusaha mendeskripsikan dan menginterpretasikan sesuatu, misalnya kondisi atau hubungan yang ada, pendapat yang berkembang, proses yang sedang berlangsung, akibat atau efek yang terjadi, atau tentang kecenderungan yang tengah berlangsung.

Pendekatan kualitatif adalah suatu pendekatan penelitian yang menggunakan data berupa kalimat tertulis atau lisan, peristiwa-peristiwa, pengetahuan atau objek studi. Proses penelitian tersebut memperhatikan konteks studi dengan menitik beratkan pada pemahaman, pemikiran persepsi peneliti.

Data yang dianalisis tidak untuk menerima atau menolak hipotesis (jika ada), melainkan hasil analisis itu bersifat deskripsi dari gejala-gejala yang diamati, yang tidak harus berbentuk angka-angka atau koefisien antarvariabel. Penelitian ini berusaha untuk melaporkan keadaan objek yang diteliti sesuai dengan apa adanya, yaitu menggambarkan sejauh mana kemampuan siswa menganalisis struktur dan kaidah kebahasaan teks negosiasi.

\section{HASIL PENELITIAN DAN PEMBAHASAN}

\section{Hasil Penelitian}

\section{Kemampuan Analisis Struktur Teks Negosiasi}

Kemampuan analisis struktur teks negosiasi siswa secara keseluruhan dapat diketahui dengan menggunakan rumus sebagai berikut.

$$
\mathrm{M}=\frac{\sum \mathrm{x}}{N}=\frac{\text { Jumla } h \text { nilai total }}{\text { Jumla } h \text { siswa }}=\frac{2.850}{37}=77
$$


Dari perhitungan tersebut, nilai yang diperoleh adalah 77. Lalu, mengacu pada kategorisasi kemampuan siswa yang dikemukakan Arikunto (2010: 168), kemampuan analisis struktur teks negosiasi oleh kelas X SMA Cinta Budaya tahun pembelajaran 2017/2018 tergolong baik.

\section{Kemampuan Analisis Kaidah Kebahasaan Teks Negosiasi}

Kemampuan analisis struktur teks negosiasi siswa secara keseluruhan juga dihitung dengan menggunakan rumus yang serupa. Dari perhitungan tersebut, nilai yang diperoleh adalah 71. Serupa dengan analisis struktur, kemampuan analisis kaidah kebahasaan ini jika dikategorisasi menggunakan tabel kemampuan siswa yang dikemukakan Arikunto (2010: 168), kemampuan oleh kelas X SMA Cinta Budaya tahun pembelajaran 2017/2018 ini juga tergolong baik.

\section{Nilai Rata-rata}

Nilai total kemampuan analisis struktur oleh siswa adalah 2.850 dan nilai total analisis kaidah kebahasaannya adalah 2.640 dengan jumlah siswa 37 orang. Dari nilai total tersebut, kita dapat mengetahui bahwa nilai rata-rata kemampuan analisis struktur adalah 77 , dan nilai rata-rata kemampuan analisis kaidah kebahasaan adalah 71 dengan menggunakan rumus berikut.

\begin{tabular}{|ll|}
\hline Nilai Rata-rata Analisis Struktur & $=\frac{\sum \mathrm{x}}{N}$ \\
& $=\frac{\text { Jumla } h \text { nil ai total }}{\text { Jumla } h \text { siswa }}$ \\
& $=\frac{2.850}{37}$ \\
& $=77$ \\
Nilai Rata-rata Analisis Kaidah Kebahasaan & $=\frac{\sum \mathrm{x}}{N}$ \\
& $=\frac{\text { Jumla } \mathrm{h} \text { nilai total }}{\text { Jumla } h \text { siswa }}$ \\
& $=\frac{2.640}{37}$ \\
& $=71$
\end{tabular}




\section{Nilai Tertinggi dan Terendah}

Data nilai akhir dihitung dengan lebih dulu mentabulasi skor mentah yang diperoleh siswa. Dari tabulasi tersebut, nilai kemampuan analisis struktur yang tertinggi 97,5 dan nilai terendah adalah 60. Sedangkan nilai kemampuan analisis kaidah kebahasaan yang tertinggi adalah 77,5 dan nilai terendahnya yaitu 52,5.

5. Persentase Kategori Kemampuan Siswa

Persentase kategori kemampuan siswa dihitung dengan menggunakan rumus sebagai berikut.

$$
\begin{aligned}
\text { Persentase Kategori Kemampuan } & =\frac{J n}{N} \times 100 \% \\
& =\frac{J u m l a ~ h \text { siswa } \text { pada kategori tertentu }}{\text { jumla } h \text { seluru } h \text { sampel }} \times 100 \%
\end{aligned}
$$

Dari perhitungan menggunakan rumus di atas, diperoleh data persentase kategori kemampuan siswa pada tabel di bawah ini.

\begin{tabular}{|c|c|c|c|c|}
\hline \multicolumn{2}{|c|}{ Skor } & Kategori & Jumlah Siswa & Persentase \\
\hline 80 & - 100 & Sangat baik & 17 & $46 \%$ \\
\hline 70 & - 79 & Baik & 12 & $32 \%$ \\
\hline 60 & - 69 & Cukup & 8 & $22 \%$ \\
\hline 50 & -59 & Kurang & 0 & $0 \%$ \\
\hline & $<49$ & Sangat Kurang & 0 & $0 \%$ \\
\hline
\end{tabular}

Tabel 1 - Persentase Kategori Kemampuan Analisis Struktur

Berdasarkan tabel persentase kategori kemampuan analisis struktur diketahui bahwa 17 (46\%) siswa berkemampuan sangat baik, $12(32 \%)$ siswa berkemampuan baik, dan $8(22 \%)$ siswa berkemampuan cukup. Sementara untuk kemampuan analisis kaidah kebahasaan, persentase dapat dilihat pada tabel di bawah ini. 
Tabel 2 - Persentase Kategori Kemampuan Analisis Kaidah Kebahasaan

\begin{tabular}{|c|c|c|c|}
\hline Skor & Kategori & Jumlah Siswa & Persentase \\
\hline $80-100$ & Sangat baik & 0 & $0 \%$ \\
\hline $70-79$ & Baik & 30 & $81 \%$ \\
\hline $60-69$ & Cukup & 4 & $11 \%$ \\
\hline $50-59$ & Kurang & 3 & $8 \%$ \\
\hline$<49$ & Sangat Kurang & 0 & $0 \%$ \\
\hline
\end{tabular}

Untuk kemampuan analisis kaidah kebahasaan, 30 (81\%) siswa berkemampuan baik, 4 (11\%) siswa berkemampuan cukup, dan $3(8 \%)$ siswa kurang mampu menganalisis kaidah kebahasaan teks negosiasi.

\section{Pembahasan Hasil Penelitian}

Berdasarkan hasil penelitian ini, diketahui bahwa hasil pembelajaran Bahasa Indonesia khususnya mengenai kemampuan siswa dalam menganalisis struktur dan kaidah kebahasaan teks negosiasi oleh siswa kelas X SMA Cinta Budaya Tahun Pembelajaran 2017/2018 tergolong "baik".

Hasil ini diperoleh melalui tugas latihan menganalisis teks negosiasi yang berjudul "Negosiasi Deadline Proposal". Dalam menganalisis struktur dan kaidah kebahasaan teks negosiasi ini, siswa tidak hanya menentukan atau memilih jawaban yang tepat, tetapi juga harus menjelaskan alasan mengapa mereka memilih suatu jawaban.

Dari latihan ini, kita juga bisa melihat apakah siswa kesulitan dalam menjelaskan analisisnya atau tidak. Sebagai contoh, bisa saja seorang siswa mampu memilih jawaban yang tepat, namun tidak bisa menjelaskan alasan pemilihannya. Kasus seperti ini ada pada beberapa lembar kerja, namun intensitasnya sangat sedikit.

Pada kemampuan analisis struktur dan nilai kemampuan analisis kaidah kebahasaan, skor pilihan dan skor alasan yang diperoleh siswa kebanyakan berjumlah sama. Bahkan, ada pula siswa yang skor penjelasannya justru lebih banyak daripada skor pilihannya. Sebagai contoh, siswa yang bernama Chanyeol 
memiliki skor mentah 27, dengan 13 pilihan yang benar dan 14 alasan yang benar. Dari data ini, dapat dikatakan bahwa siswa kelas X SMA Cinta Budaya memiliki kemampuan menjelaskan yang cukup baik.

Berbicara mengenai perbandingan nilai antara analisis struktur dan analisis kaidah kebahasaan teks negosiasi, nilai yang diperoleh siswa pada kedua aspek ini bervariasi. Ada siswa yang lebih tinggi nilai analisis strukturnya, ada siswa yang lebih tinggi nilai analisis kaidah kebahasaannya, namun ada pula siswa yang mendapat nilai yang sama pada kedua aspek tersebut. Akan tetapi, jika kita melihat skor rata-rata seluruh siswa dari kedua aspek itu, nilai analisis struktur lebih unggul di angka 77, sedangkan nilai analisis kaidah kebahasaan hanya 71.

Dalam beberapa contoh lembar siswa, pada bagian analisis kaidah kebahasaan, banyak siswa yang salah menentukan jenis kalimat bernomor 11 dan 19. Kalimat nomor 19 merupakan kalimat bersyarat, begitu juga dengan kalimat nomor 11 yang adalah kalimat bersyarat namun juga mengandung unsur kausalitas. Artinya, pada kalimat nomor 11, peneliti membenarkan jawaban "bersyarat" maupun jawaban "kausalitas". Akan tetapi, kebanyakan siswa justru menjawabnya sebagai kalimat perintah, sebab kebanyakan dari mereka terfokus pada tanda seru (!) yang berada di akhir kalimat.

Contoh jawaban lain yang juga mencolok untuk dijelaskan adalah jawaban milik Widelia pada bagian analisis kaidah kebahasaan. Widelia benar dalam menentukan jenis kalimat, dalam hal ini kalimat yang dimaksud adalah kalimat tanya. Akan tetapi, alasan pemilihannya hanyalah berdasarkan tanda tanya yang berada pada akhir kalimat. Tidak hanya Widelia, peneliti juga menemukan beberapa jawaban serupa pada lembar kerja siswa yang lain. Hal ini menunjukkan bahwa beberapa siswa kelas X SMA Cinta Budaya Tahun Pembelajaran 2017/2018, masih kurang memahami jenis-jenis kalimat yang ada. Hal ini juga sesuai dengan persentase kategori kemampuan siswa menganalisis kaidah kebahasaan pada tabel 4.5 yang menunjukkan bahwa $8 \%$ siswa kelas X SMA Cinta Budaya dalam hal ini kemampuannya masih kurang.

Berbeda dengan analisis kaidah kebahasaan, dalam hal menganalisis struktur, siswa kelas X SMA Cinta Budaya tergolong cukup, bahkan hampir 
setengahnya berkemampuan sangat baik. Perbedaan ini dapat terjadi karena pelajaran mengenai struktur teks negosiasi adalah pelajaran yang baru mereka pelajari, sedangkan pelajaran mengenai kalimat menurut fungsinya adalah pelajaran yang dipelajari di bangku sekolah dasar. Kualitas pengajaran di bangku SD, ditambah dengan jarak waktu pelajaran yang lama (SD ke SMA), dapat menjadi penyebab kemampuan analisis kaidah kebahasaan yang cenderung lebih rendah daripada kemampuan analisis struktur teks negosiasi.

\section{DAFTAR PUSTAKA}

Arikunto, Suharsimi. 2010. Prosedur Penelitian: Suatu Pendekatan Praktik. (Edisi Revisi). Jakarta: Rineka Cipta.

Bangun, Devi Srita Ulina. 2016. Pengaruh Model Pembelajaran Inkuiri terhadap Kemampuan Menganalisis Teks Negosiasi oleh Siswa Kelas X SMA Negeri 2 Kabanjahe Tahun Pembelajaran 2015/2016. Skripsi. Medan: Fakultas Bahasa dan Seni Universitas Negeri Medan.

Buyung, Ahmad. 2009. Analisis Pengaruh NPL, CAR, LDR, dan BOPO terhadap Profitabilitas Bank. Tesis. Semarang: Universitas Diponegoro.

Depdiknas. 2008. Kamus Besar Bahasa Indonesia. Edisi ke 4. Jakarta: Gramedia Pustaka Utama.

Hasibuan, Reza Arezda. 2016. Hubungan Pemahaman Isi, Struktur, dan Ciri Kebahasaan dengan Kemampuan Menganalisis Teks Negosiasi Siswa Kelas XI SMA Swasta Krakatau Medan Tahun Pembelajaran 2016/2017. Skripsi. Medan: Fakultas Bahasa dan Seni Universitas Negeri Medan.

Kemdikbud. 2015. Buku Guru Bahasa Indonesia Kelas X SMA. Jakarta: Pusat Kurikulum dan Perbukuan Kemdikbud.

2015. Buku Siswa Bahasa Indonesia Kelas X SMA. Jakarta: Pusat Kurikulum dan Perbukuan Kemdikbud.

Khoirot, Umur Dika. 2011. Kemampuan Mengidentifikasi Struktur Alur Cerpen Gadis Berjaket Merah Karya Donatus Nugroho pada Siswa Kelas X SMA Tri Sukses Natar Tahun Pembelajaran 2010/2011. Skripsi. Lampung: FKIP Universitas Lampung.

Kosasih, Engkos. 2013. Cerdas Berbahasa Indonesia. Jakarta: Erlangga.

Mahsun. 2014. Teks dalam Pembelajaran Bahasa Indonesia Kurikulum 2013. Jakarta: Raja Grafindo Persada. 
Mulyasa. 2014. Pengembangan dan Implementasi Kurikulum 2013. Bandung: Rosda.

Ningsi, Sulis Fitria. 2014. Pengaruh Model Project-Based Learning terhadap Kemampuan Menulis Teks Negosiasi Siswa Kelas X SMAN 1 Kuala Tahun Pembelajaran 2014/2015. Skripsi. Medan: Fakultas Bahasa dan Seni Universitas Negeri Medan.

Purba, Adelita. 2015. Pengaruh Model Pembelajaran Discovery Learning terhadap Kemampuan Memproduksi Teks Negosiasi Siswa Kelas X SMAN 20 Medan Tahun Pembelajaran 2014/2015. Skripsi. Medan: Fakultas Bahasa dan Seni Universitas Negeri Medan.

Saragih, Renita. 2016. Pengaruh Penggunaan Video terhadap Kemampuan Menulis Teks Negosiasi Siswa Kelas X SMKN 1 Lubuk Pakam Tahun Pembelajaran 2015/2016. Skripsi. Medan: Fakultas Bahasa dan Seni Universitas Negeri Medan.

Soelaiman. 2007. Manajemen Kinerja; Langkah Efektif untuk Membangun, Mengendalikan dan Evaluasi Kerja. Jakarta: PT Intermedia Personalia Uama.

Susiyanti Dewi, Nengah Suandi, dan Nyoman Yasa. 2015. Implemantasi Pembelajaran Menulis Teks Negosiasi Berdasarkan Kurikulum 2013 di Kelas X-B Akuntansi SMK Negeri 1 Singajara. e-Journal: Jurusan Pendidikan Bahasa dan Sastra Indonesia Undiksha, III (1).

Tarigan, Henry Guntur. 2008. Menulis sebagai Suatu Keterampilan Berbahasa. Bandung: Angkasa.

Wiradi, Gunawan. 2009. Metodologi Studi Agraria. Bogor: Sajogyo Institute. 